\title{
Cell wall composition of the skin and flesh tissue of crisp and standard texture southern highbush blueberry genotypes
}

\author{
Kendra M. Blaker and James W. Olmstead* \\ Horticultural Sciences Department, University of Florida, Gainesville, FL, USA
}

\begin{abstract}
.
BACKGROUND: Blueberry cultivars with very firm, crisp fruit textures have been developed to increase consumer acceptance and as an aid in production and marketing. The basis for the crisp fruit texture is unknown.

OBJECTIVES: The objective of this study was to compare the bioyield force (BF) and cell wall composition of crisp and standard texture blueberry genotypes.

METHODS: Bioyield force of seven southern highbush blueberry genotypes having standard ('Springhigh', 'Star', Windsor') and crisp ('Sweetcrisp', FL06-561, FL06-562, and FL98-325) fruit texture was measured on fresh, whole fruits. Dry weight, alcohol insoluble residue (AIR), uronic acids (UA), and neutral sugars (NS) were then measured on separated flesh and skin tissue.

RESULTS: The BF of the standard texture genotypes was significantly less than all four crisp genotypes. There were differences in the dry weight and AIR among genotypes, but these differences did not correspond to crisp and standard texture classes. There was no significant difference among genotypes in the measurement of UA or NS.

CONCLUSIONS: These results confirm that there is a phenotypic difference between crisp and standard texture blueberry genotypes that can be detected with BF measurements, but that quantitative differences among total cell wall material, pectins, and neutral sugars were not responsible for the variability of these texture types.
\end{abstract}

Keywords: Uronic acids, pectin, neutral sugars, hemicellulose, dry weight, bioyield force, Vaccinium corymbosum, epidermis, mesocarp

\section{Introduction}

Three southern highbush blueberry (Vaccinium corymbosum L. interspecific hybrids) cultivars ('Bluecrisp', 'Sweetcrisp', and 'Indigocrisp ${ }^{\mathrm{TM}}$ ') released by the University of Florida (UF) in 1997, 2005, and 2013, respectively, are considered to have a unique crisp texture $[1,2]$. Many current selections in the UF blueberry breeding program are also considered to have a similar crisp phenotype, and other cultivars such as 'Reveille', 'Dolores', and 'Hortblue Poppins' have descriptions that indicate they would be classified as having crisp texture [1, 3, 4]. Berries with this crisp texture are of particular interest due to their enhanced eating quality, prolonged postharvest life, and potential value for mechanical harvesting for fresh marketed blueberries [5-8]. Understanding the physiological basis of this trait would potentially aid in selection and improvement through breeding efforts.

Several fresh market fruit species having textures that range from soft to crisp have been identified, including apple, grape (Vitis vinifera L), peach (Prunus persica L.), and sweet cherry (Prunus avium L.) [9-12]. When 'Honeycrisp'

*Corresponding author: James W. Olmstead, University of Florida, Institute for Food and Agricultural Sciences, Horticultural Sciences Department, 2211 Fifield Hall, Gainesville, FL 32611, USA. Tel.: +1 352273 4837; E-mail: jwolmstead@ufl.edu. 
apple was compared to non-crisp apple cultivars, maintenance of crisp texture after storage was attributed to high turgor potential and cell wall integrity, but not correlated with cell wall neutral sugars [9]. In 'Big Top' nectarine, the firm, crisp texture at maturity that was similar to other stony hard cultivars was a result of delayed onset of ethylene production and not differences in endo-polygalacturonase expression [10]. When crisp and soft fruit of the same cherry cultivar were evaluated, polymerization of pectin side chains appeared to contribute to crisp texture [11]. In contrast, little is known about the physiological basis of crisp texture in blueberry.

The strength and thickness of cell walls have been considered to have the greatest overall impact on fruit firmness and texture $[13,14]$, and the crisp phenotype in blueberries may be related to some aspect of cell wall thickness. Primary cell walls form a complex matrix of approximately $30-40 \%$ cellulose, $30 \%$ hemicellulose, $15-30 \%$ pectin, and 5-10\% structural protein [15]. In blueberry, pectins comprise 30-35\% of the total cell wall, but xylose exceeded glucose content enough to suggest the presence of xylans rather than xyloglucans as the principal hemicellulosic component [16]. Secondary cell walls typically have lignin and a higher proportion of cellulose, a lower proportion of pectin, and hemicelluloses that are more abundant in xylans and glucomannans which bind more tightly to cellulose $[17,18]$. Highly lignified sclereid cells just beneath the epidermal cell layer have been identified in several blueberry cultivars [19-22]. These sclereid cells may account for the increased levels of xylose observed by Vicente et al. [16] in the walls of ripening blueberry fruit, but have not been associated with crisp blueberry texture [22].

Textural modifications during fruit softening consist mostly of changes to the mechanical strength of the cell wall and adhesion between cells at the middle lamella [13]. These changes are primarily the result of the enzyme-initiated solubilization and depolymerization of pectins and hemicelluloses [13]. Depolymerization of pectins is considered to be one of the most influential and yet variable factors involved in fruit softening of different species [15, 23]. For example, depolymerization of ionically bound cyclohexane diamine tetraacetic acid (CDTA)-soluble pectins is evident in avocado (Persea americana Mill.), but virtually absent in pepper (Capsicum annuum L.), banana (Musa spp.), and apple (Malus domestica Borkh.) [23]. Sodium carbonate soluble pectins are composed of ester-bound glycans, and are a primary component of the middle lamella where cell-to-cell adhesion is maintained [23]. Pectin solubilization has been related to swelling of the cell wall in several melting flesh fruits, but both pectin solubilization and cell wall swelling were diminished in the crisp fruits of apple, watermelon (Citrullus lanatus Thunb.), and pear (Pyrus communis L.) [24]. In blueberry, cell wall degradation is marked by pectin solubilization in the early and intermediate stages of ripening, and increased solubilization of arabinose from pectins and hemicelluloses in the later stages of ripening [16]. The depolymerization of hemicelluloses was detected in all ripening stages (green to ripe fruits), but Vicente et al. [16] did not find evidence of pectin depolymerization during fruit softening.

The objective of this study was to compare the BF, dry weight, total cell wall material, total pectins, and neutral sugars between crisp and standard texture blueberry genotypes.

\section{Materials and methods}

\subsection{Plant material}

Seven southern highbush blueberry genotypes having standard ('Springhigh', 'Star', Windsor') and crisp ('Sweetcrisp', FL06-561, FL06-562, and FL98-325) fruit texture were selected for use in this study. Selection of these genotypes was based on texture classification by a trained sensory panel to identify standard and crisp texture genotypes [1].

Because not all genotypes were available at the same location, experiments followed an incomplete block design in which three replications were collected from seven genotypes at two field locations (out of five possible locations) for a total of six replicates per genotype. Location was used as a random effect in the statistical model. Cultivars and selections were hand harvested from three commercial field plots near Waldo, FL and Windsor, FL, and from two field plots at the University of Florida Plant Science Research and Education Unit near Citra, FL.

Each replication consisted of approximately $250 \mathrm{~g}$ of fruit. Fully ripe, unblemished berries were harvested in white plastic $4 \mathrm{~L}$ buckets, stored in coolers filled with ice, and transported on the same day to the blueberry breeding lab at the University of Florida in Gainesville, FL for BF analysis. After BF was measured for fresh fruit (see below for details), all berries were frozen in liquid nitrogen and stored at $-80^{\circ} \mathrm{C}$ for later biochemical analyses. 


\subsection{Instrumental analysis}

Bioyield force was measured on a 25 berry subsample from each replicate. Individual berries were oriented equatorially upright [25] and punctured with a $4 \mathrm{~mm}$ probe using a TA.HD plus Texture Analyzer (Texture Technologies Corp., Scarsdale, New York). Bioyield force $(\mathrm{N})$ was measured as the maximum force required to puncture a berry at a speed of $50 \mathrm{~mm} \cdot \mathrm{min}^{-1}$.

\subsection{Sample preparation}

The remaining fruit after BF measurements (approximately $200 \mathrm{~g}$ ) were peeled by hand and skin was removed from the flesh prior to measuring fresh weight and freeze drying with a Freezone 1 freeze drier (Labconco Corporation, Kansas City, MO). Dry weight was calculated from freeze dried samples and powders were obtained by grinding with a mortar and pestle.

\subsection{Alcohol insoluble residue (AIR) isolation}

Total cell wall material was isolated as the AIR. The isolation was performed using the procedure described by Vicente et al. [16] with the following changes. Approximately $30 \mathrm{~mL}$ of $95 \%$ ethanol was added to approximately 2 and $6 \mathrm{~g}$ of powder from berry skins and flesh respectively. Suspensions were boiled for 45 min to inactivate enzymes, centrifuged $(17,000 \mathrm{~g}$, for $20 \mathrm{~min}$ ), and the insoluble residue was washed $3 \times$ with approximately $30 \mathrm{~mL}$ of $95 \%$ ethanol, followed by chloroform/methanol $(1: 1 \mathrm{v} / \mathrm{v})$, and finally acetone. The weight of the AIR was recorded after drying overnight at $37^{\circ} \mathrm{C}$.

\subsection{Uronic acid (UA) and neutral sugar (NS) measurement}

Following the methods of Ahmed and Labavitch [26], $2.5 \mathrm{mg}$ of AIR was weighed into $16 \times 100 \mathrm{~mm}$ disposable glass culture tubes and placed in ice on a shaker. Two $\mathrm{mL}$ of chilled $95 \%$ sulfuric acid was added to each tube by small increasing amounts over the course of 30 minutes.

The amounts of UA and neutral sugars NS were measured using microtiter plate methodology as described by van den Hoogen et al. [27] and Laurentin and Edwards [28], respectively. For the measurement of UA, a 96 well microtiter plate (Costar, Corning, NY) was kept on ice, and each well was filled with $40 \mu \mathrm{L}$ of sample and $200 \mu \mathrm{L}$ of $95 \%$ sulfuric acid containing $120 \mathrm{mM}$ sodium tetraborate that had been mixed overnight using a stir bar and plate. Each plate contained 24 samples, a blank, and seven standards of galacturonic acid $(0.5,1,1.5,2,4,6$, and $8 \mu \mathrm{g})$ in triplicate. The plate was covered with an adhesive plate sealer and placed in a water bath for one hour at $85^{\circ} \mathrm{C}$. The plate was cooled and centrifuged at low speed for $30 \mathrm{~s}$. Background absorbance was measured at $520 \mathrm{~nm}$ using a Synergy HT microplate reader and Gen5 microplate software for Windows (BioTek, Winooski, VT). The reaction was initiated with $40 \mu \mathrm{L}$ of $m$-hydroxydiphenyl solution $\left(100 \mu \mathrm{L}\right.$ of $100 \mathrm{mg} \cdot \mathrm{mL}^{-1} m$-hydroxydiphenyl in dimethyl sulfoxide stored away from light at $4{ }^{\circ} \mathrm{C}$ was mixed with $4.9 \mathrm{~mL} 80 \%$ sulfuric acid just prior to use). The plate was covered again, with adhesive plate sealer, inverted several times to mix the sample, and centrifuged at low speed for $30 \mathrm{~s}$. Absorbance was measured after $10 \mathrm{~min}$ at $520 \mathrm{~nm}$.

For the measurement of NS, $40 \mu \mathrm{L}$ of sample was added to each well of a 96 well microtiter plate with removable $1 \times 8$ strip assemblies (Immulon $4 \mathrm{HBX}$, Milford, MA) while on ice. Each plate contained 24 samples, a blank, and seven glucose standards $(0.5,1,1.5,2,4,7$, and $10 \mu \mathrm{g})$ in triplicate. The reaction was initiated with $100 \mu \mathrm{L}$ anthrone solution ( $2 \mathrm{~g} \cdot \mathrm{L}^{-1}$ anthrone in $95 \%$ sulfuric acid), the plate was covered with plate sealer, and mixed gently using a vortex. The wells were removed from the plate and suspended in a water bath at $92^{\circ} \mathrm{C}$ for 3 min., and then cooled in a water bath at room temperature for $5 \mathrm{~min}$. The plate was centrifuged for $30 \mathrm{~s}$ at low speed and after $20 \mathrm{~min}$ from when the anthrone solution was added, the absorbance was read at $630 \mathrm{~nm}$. The amount of UA and NS $\left(\mu \mathrm{g} \cdot \mathrm{mg}^{-1}\right.$ AIR) of each sample was calculated from the absorbance readings of standards used to form a calibration curve. 


\subsection{Statistical analysis}

ANOVA was performed using the GLIMMIX procedure and Kenward-Roger method (SAS 9.2) with genotype as a fixed effect and location as a random effect. Tukey's HSD (honestly significant difference) test was used to determine significant differences $(P \leq 0.05)$ among genotypes and treatments.

\section{Results and discussion}

The BF of 'Sweetcrisp' $(4.89 \mathrm{~N}$ ) was significantly greater than all other genotypes (Fig. 1). The BF of the three standard texture genotypes ('Springhigh', 'Star', 'Windsor') were not significantly different from each other, and were less than all four crisp genotypes ('Sweetcrisp', FL06-561, FL06-562, and FL98-325). These results are consistent with those from Blaker et al. [1], where BF of several crisp and standard texture genotypes were highly correlated with sensory evaluations of texture by a trained panel.

Dry weight, AIR, UA, and NS content were measured in the separated flesh and skin tissues of each genotype, and compared between crisp and standard texture genotypes (Table 1). The dry weight of flesh tissue ranged from 12.8 to $17.1 \%$ fresh weight (FW) and from 20.9 to $26.8 \% \mathrm{FW}$ for skin tissue (Table 1). Flesh dry weight of 'Sweetcrisp' was greater than other genotypes and supported the expectation that crisp fruit would have more dry matter accounting for their increased firmness. However, the flesh dry weight of crisp genotypes FL06-561 and FL06-562 were the same or significantly less than those of standard texture genotypes (Table 1). A similar pattern was observed for skin dry weight, with the crisp texture genotype FL06-562 having the greatest skin dry weight. However, the standard texture genotypes 'Windsor' and 'Springhigh' were not significantly different from FL06-562.

AIR was expressed in milligrams per $100 \mathrm{mg} F W$ and ranged from 1.10 to $1.56 \mathrm{mg} \cdot 100 \mathrm{mg}^{-1}$ in the flesh of ripe fruit and from 5.87 to $9.61 \mathrm{mg} \cdot 100 \mathrm{mg}^{-1}$ in the skins of ripe fruit (Table 1). The amount of AIR in whole blueberry fruit from the northern highbush cultivar 'Duke' was measured by Vicente et al. [16] to be approximately 3 to $4 \mathrm{mg} \cdot 100 \mathrm{mg}^{-1}$ and is therefore considered to be consistent with the AIR values we obtained from flesh and skin tissue separately. In the present study, genotypes differed in the

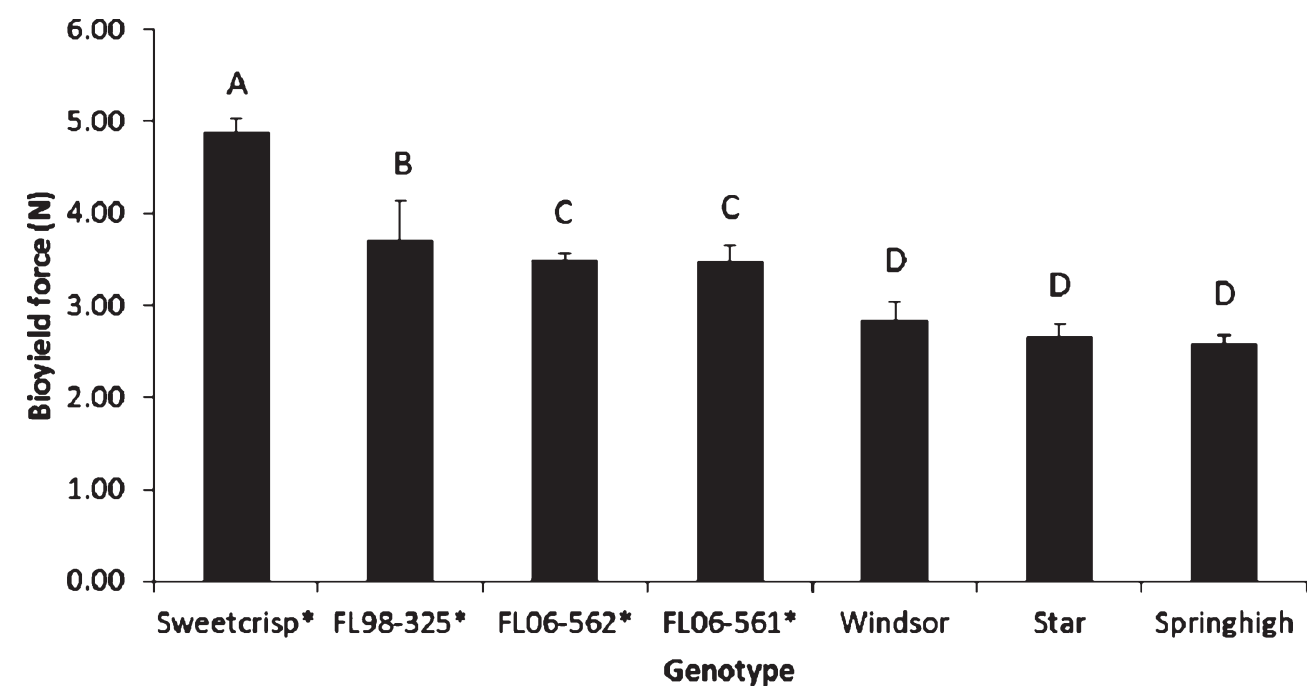

Fig. 1. Bioyield force measurements $(\mathrm{N})$ of four crisp (denoted by *) and three standard texture southern highbush blueberry genotypes. Bioyield measurements were made immediately after harvest using fresh, mature blue fruit. Error bars indicate standard deviation of six replicates per genotype. Different letters above graph bars indicate significant differences $(P<0.05)$ among genotypes as determined by Tukey's HSD test. 
Table 1

Dry weight (DW; \% fresh weight), alcohol insoluble residue (AIR; mg. $100 \mathrm{mg}^{-1}$ ), uronic acids (UA; $\mu \mathrm{g} \cdot \mathrm{mg}^{-1}$ ), and neutral sugars (NS; $\mu \mathrm{g} \cdot \mathrm{mg}^{-1}$ ) of flesh and skin tissue from crisp (denoted by*) and standard texture southern highbush blueberry genotypes. Least squares means and standard deviation are based on six replicates per genotype. Fruit were harvested at the mature blue stage of fruit development, and skin and flesh tissues were separated prior to analyses

\begin{tabular}{|c|c|c|c|c|c|}
\hline Tissue & Genotype & DW $(\% \text { fresh wt. })^{\mathrm{z}}$ & AIR (mg. $\left.100 \mathrm{mg}^{-1}\right)$ & $\mathrm{UA}\left(\mu \mathrm{g} \cdot \mathrm{mg}^{-1}\right)$ & $\mathrm{NS}\left(\mu \mathrm{g} \cdot \mathrm{mg}^{-1}\right)$ \\
\hline \multirow[t]{7}{*}{ Flesh } & Sweetcrisp* & $17.1 \pm 1.7 \mathrm{~A}$ & $1.31 \pm 0.24 \mathrm{AB}$ & $187 \pm 73 \mathrm{~A}$ & $577 \pm 165 \mathrm{~A}$ \\
\hline & FL98-325* & $15.2 \pm 1.7 \mathrm{AB}$ & $1.43 \pm 0.24 \mathrm{~A}$ & $251 \pm 73 \mathrm{~A}$ & $591 \pm 165 \mathrm{~A}$ \\
\hline & Star & $15.2 \pm 1.7 \mathrm{AB}$ & $1.31 \pm 0.24 \mathrm{AB}$ & $241 \pm 73 \mathrm{~A}$ & $579 \pm 165 \mathrm{~A}$ \\
\hline & Windsor & $15.1 \pm 1.8 \mathrm{ABC}$ & $1.56 \pm 0.25 \mathrm{~A}$ & $228 \pm 73 \mathrm{~A}$ & $620 \pm 165 \mathrm{~A}$ \\
\hline & FL06-561* & $14.3 \pm 1.7 \mathrm{BC}$ & $1.33 \pm 0.25 \mathrm{AB}$ & $248 \pm 73 \mathrm{~A}$ & $464 \pm 165 \mathrm{~A}$ \\
\hline & Springhigh & $14.1 \pm 1.7 \mathrm{BC}$ & $1.10 \pm 0.24 \mathrm{~B}$ & $194 \pm 73 \mathrm{~A}$ & $464 \pm 165 \mathrm{~A}$ \\
\hline & FL06-562* & $12.8 \pm 1.7 \mathrm{C}$ & $1.38 \pm 0.25 \mathrm{AB}$ & $214 \pm 73 \mathrm{~A}$ & $540 \pm 165 \mathrm{~A}$ \\
\hline \multirow[t]{7}{*}{ Skin } & FL06-562* & $26.8 \pm 4.5 \mathrm{~A}$ & $9.61 \pm 2.70 \mathrm{~A}$ & $286 \pm 96 \mathrm{~A}$ & $426 \pm 106 \mathrm{~A}$ \\
\hline & Sweetcrisp* & $26.5 \pm 4.5 \mathrm{~A}$ & $8.21 \pm 2.53 \mathrm{~A}$ & $228 \pm 83 \mathrm{~A}$ & $418 \pm 87 \mathrm{~A}$ \\
\hline & FL 06-561* & $25.8 \pm 4.5 \mathrm{~A}$ & $8.14 \pm 2.53 \mathrm{~A}$ & $243 \pm 88 \mathrm{~A}$ & $444 \pm 95 \mathrm{~A}$ \\
\hline & Windsor & $23.9 \pm 4.5 \mathrm{AB}$ & $7.87 \pm 2.46 \mathrm{~A}$ & $251 \pm 89 \mathrm{~A}$ & $395 \pm 87 \mathrm{~A}$ \\
\hline & Springhigh & $23.9 \pm 4.3 \mathrm{AB}$ & $9.52 \pm 2.50 \mathrm{~A}$ & $285 \pm 82 \mathrm{~A}$ & $488 \pm 87 \mathrm{~A}$ \\
\hline & FL98-325* & $21.6 \pm 4.3 \mathrm{~B}$ & $5.91 \pm 2.35 \mathrm{~A}$ & $284 \pm 81 \mathrm{~A}$ & $436 \pm 87 \mathrm{~A}$ \\
\hline & Star & $20.9 \pm 4.2 \mathrm{~B}$ & $5.87 \pm 2.29 \mathrm{~A}$ & $265 \pm 81 \mathrm{~A}$ & $437 \pm 87 \mathrm{~A}$ \\
\hline
\end{tabular}

${ }^{z}$ Different letters in a column of the same tissue origin indicate significant differences $(P<0.05)$ among genotypes as determined by Tukey's HSD test.

amount of AIR measured from only flesh tissue, suggesting that genotypes vary in their amount of cell wall material. However, differences among genotypes were unrelated to the textural categories of standard and crisp (Table 1).

Uronic acids (UA) and neutral sugars (NS) were measured as micrograms per milligram of AIR. UA, representing the primary pectin constituents in the cell wall, ranged from 187 to $251 \mu \mathrm{g} \cdot \mathrm{mg}^{-1}$ in the flesh of ripe fruit and from 228 to $286 \mu \mathrm{g} \cdot \mathrm{mg}^{-1}$ in the skins of ripe fruit. These values were lower than those obtained from the measure of UA in whole blueberry fruits from the cultivar 'Duke', which ranged from 311 to $344 \mu \mathrm{g} \cdot \mathrm{mg}^{-1}$ AIR [16]. Color production by uronic acids is reduced in the presence of interfering neutral sugars, and despite efforts to minimize interference by reducing the reaction temperature and measuring background absorbance, browning from neutral sugars may have interfered with UA absorbance readings [27]. NS ranged from 464 to $620 \mu \mathrm{g} \cdot \mathrm{mg}^{-1}$ in the flesh of ripe fruits and from 395 to $488 \mu \mathrm{g} \cdot \mathrm{mg}^{-1}$ in the skins of ripe fruit. These values are consistent with those measured by Vicente et al. [16] in the blueberry cultivar 'Duke'. There was no significant difference among genotypes in the measurement of UA or NS.

To further pursue an explanation of these differences, the AIR could be separated into fractions based on the solubility of cell wall components in which polymer sizes are measured and specific neutral sugars are identified [23]. Further in depth studies could also be pursued with the use of monoclonal antibodies which bind specific cell wall polymers that may help identify structural differences between crisp and standard texture berries [29]. Atomic force microscopy was used to image hemicelluloses in Chinese cherry (Prunus pseudocerasus L.), and revealed that the branching pattern of hemicellulose in crisp fruit was oriented in the same direction, but was more irregular in soft fruits. Length of branch chain was unrelated to texture type, but crisp varieties had wider branches and a higher frequency of wide branched chains [30]. Crisp texture in blueberry may also be a result of structural variations in the substitution and branching patterns of the pectic and hemicellulosic components.

Together, these results confirm that there is a phenotypic difference between crisp and standard texture blueberry genotypes that can be detected with BF measurements, but that gross quantitative measures of total cell wall material, pectins, and neutral sugars are not descriptive enough to detect the physiological basis of these differences. 


\section{Acknowledgments}

The authors thank Straughn Farms for the use of their plant material. We also thank D. Huber and W. Vermerris for comment and critical review of this manuscript, and J. Colee for statistical consultation.

\section{References}

[1] Blaker K, Plotto A, Baldwin E, Olmstead J. Correlation between sensory and instrumental measurements of soft and crisp textured southern highbush blueberries. Postharvest Biol Technol. 2014;94:2785-93.

[2] Okie WR. Register of new fruit and nut varieties - List 39. HortScience. 1999;34:181-205.

[3] Clark JR, Finn CE. Register of new fruit and nut cultivars: List 45. HortScience. 2010;45:716-56.

[4] Scalzo J, Dierking S, Dierking W, Miller S, Edwards C, Alspach P. 'Hortblue Poppins': New cultivar for the home garden. Acta Hortic. 2009;810:157-62.

[5] Padley L. Firmness and storage characteristics of crisp-textured blueberries. University of Florida Thesis. 2005.

[6] Mehra LK, MacLean DD, Savelle AT, Scherm H. Postharvest disease development on southern highbush blueberry fruit in relation to berry flesh type and harvest method. Plant Dis. 2013;97:213-21.

[7] Takeda T, Krewer G, Li C, MacLean D, Olmstead JW. Techniques for increasing machine-harvest efficiency in blueberries. Horttechnology. 2013;23:430-6.

[8] Olmstead JW, Finn CE. Breeding highbush blueberry cultivars adapted to machine harvest for the fresh market. Horttechnology. 2014;24:290-4.

[9] Tong C, Krueger D, Vickers Z, Bedford D, Luby J, El-Shiekh A, Shackel K, Ahmadi H. Comparison of softening-related changes during storage of 'Honeycrisp' apple, its parents, and 'Delicious'. J Am Soc Hortic Sci. 1999;124:407-15.

[10] Ghiani A, Negrini N, Morgutti S, Baldin F, Nocito FF, Spinardi A, Mignani I, Bassi D, Cocucci M. Melting of 'Big Top' nectarine fruit: Some physiological, biochemical, and molecular aspects. J Am Soc Hortic Sci. 2011;136:61-8.

[11] Batisse C, Buret M, Coulomb PJ. Biochemical differences in cell wall of cherry fruit between soft and crisp fruit. J Agric Food Chem. 1996;44:453-7.

[12] Sato A, Yamada M, Iwanami H. Estimation of the proportion of offspring having genetically crispy flesh in grape breeding. J Am Soc Hortic Sci. 2006;131:46-52.

[13] Goulao LF, Oliveira CM. Cell wall modifications during fruit ripening: When a fruit is not the fruit. Trends Food Sci Technol. 2008;19: 4-25.

[14] Li X, Xu C, Korban SS, Chen K. Regulatory mechanisms of textural changes in ripening fruits. CRC Crit Rev Plant Sci. 2010;29: 222-43.

[15] Vermerris W. Composition and biosynthesis of lignocellulosic biomass. In: W. Vermerris ed. Genetic improvement of Bioenergy crops. New York: Springer; 2008, pp. 89-142.

[16] Vicente AR, Ortugno C, Rosli H, Powell ALT, Greve LC, Labavitch JM. Temporal sequence of cell wall disassembly events in developing fruits. 2. Analysis of blueberry (Vaccinium Species). J Agric Food Chem. 2007;55:4125-30.

[17] Knox JP. Revealing the structural and functional diversity of plant cell walls. Curr Opin Plant Biol. 2008;11:308-13.

[18] Hatfield R, Vermerris W. Lignin formation in plants-The dilemma of linkage specificity. Plant Physiol. 2001;126:1351-7.

[19] Fava J, Alzamora SM, Castro MA. Structure and nanostructure of the outer tangential epidermal cell wall in Vaccinium corymbosum L. (Blueberry) fruits by blanching, freezing-thawing and ultrasound. Food Sci Technol Int. 2006;12:241-51.

[20] Gough RE. The occurrence of mesocarpic stone cells in the fruit of cultivated highbush blueberry. J Am Soc Hortic Sci. 1983;108: 1064-7.

[21] Allan-Wojtas PM, Forney CF, Carbyn SE, Nicholas K. Microstructural indicators of quality-related characteristics of blueberries - An integrated approach. Lebenson Wiss Technol. 2001;34:23-32.

[22] Blaker KM, Olmstead, JW. Stone cell frequency and cell size variation of crisp and soft textured fruits from nine southern highbush blueberry cultivars. J Am Soc Hortic Sci. 2014;139:553-7.

[23] Brummell DA. Cell wall disassembly in ripening fruit. Funct Plant Biol. 2006;33:103-19.

[24] Redgwell RJ, MacRae E, Hallett I, Fischer M, Perry J, Harker R. In vivo and in vitro swelling of cell walls during fruit ripening. Planta. 1997;203:162-73.

[25] Ehlenfeldt MK, Martin RB. A survey of fruit firmness in highbush blueberry and species-introgressed blueberry cultivars. HortScience. 2002;37:386-9.

[26] Ahmed AER, Labavitch JM. A simplified method for accurate determination of cell wall uronide content. J Food Biochem. 1977;1:361-5.

[27] van den Hoogen BM, van Weeren PR, Lopes-Cardozo M, van Golde LM, Barneveld A, van de Lest CH. A microtiter plate assay for the determination of uronic acids. Anal Biochem. 1998;257:107-11. 
[28] Laurentin A, Edwards CA. A microtiter modification of the anthrone-sulfuric acid colorimetric assay for glucose-based carbohydrates. Anal Biochem. 2003;315:143-5.

[29] Willats WGT, Knox JP, Mikkelsen JD. Pectin: New insights into an old polymer are starting to gel. Trends Food Sci Technol. 2006;17:97-104.

[30] Chen F, Zhang L, An H, Yang H, Sun X, Liu H, Yao Y, Li L. The nanostructure of hemicellulose of crisp and soft Chinese cherry (Prunus pseudocerasus L.) cultivars at different stages of ripeness. Lebenson Wiss Technol. 2009;42:125-30. 